
www.globaljournalseries.com; globaljournalseries@gmail.com

\title{
EDUCATION AND THE ACHIEVEMENT OF NATIONAL DEVELOPMENT THROUGH GIRL CHILD EMPOWERMENT IN NIGERIA
}

ONAH, PETER OGBAJI, MARTHA EDU AKANIMOH AND NDOME, LINDA ESSE

(Received 10 June 2021 Revision Accepted 13, August 2021)

\begin{abstract}
Education plays a very pertinent role in promoting development, as it is concerned with imparting knowledge, skills, attitudes, belief systems and values. This paper focuses on the utilization of the girl child education as an effective tool to foster national development. It conceptualized education, girl child education, empowerment and National Development. The theory of functionalism was adopted to offer credence to the paper. This paper vividly explicates how various negative attitudes and negligence towards the girl child education in African continent in general and Nigeria to be specific has exacerbated poverty, illiteracy and untold hardship on the citizenry. It further unraveled the strategies for using girl child education as an instrument for national development thereby eradicating poverty in Nigeria. Based on the issues raised in the paper, as education remains a formidable weapon of socioeconomic development of any nation, the paper recommends the need for change in the Nigerian policy towards education, especially the girl child education by improving public budget in education, improve education for self-reliance, to enhance educational efficiency by improving on skills learning via entrepreneurship education and building of critical and objective reasoning, and girl child empowerment.
\end{abstract}

KEYWORDS: Education, Empowerment, Girl Child Education, National Development and Poverty.

\section{INTRODUCTION}

Poverty is a multi-dimensional phenomenon that, there is no country in the world that can boast of being free of it, or that can claim of being totally eradicated in all dimensions. Contrary to the general postulation and understanding of people over poverty, the term in its sleepy nature carries various connotations due to its multiple natures, as poverty in one country or family is richness in another. Gatewood cited in Horton and Hunt (2006) view poverty indifferent dimension that, what is consider as poverty in the United State may be relatively comfort in a less affluent society. Observers and policy makers now accept a multi-dimensional definition of poverty, which includes certain "non-quantifiable" attributes such as discrimination, social exclusion, exploitation and deprivation of dignity (UNICEF, 2000). Education is accepted globally as a major

Onah, Peter Ogbaji, Department of Educational Foundations Faculty of Education University of Calabar, Calabar

Martha Edu Akanimoh, Department of Educational Foundations Faculty of Education University of Calabar, Calabar

Ndome, Linda Esse, Department of Educational Foundations Faculty of Education University of Calabar, Calabar 
instrument for social transformation, technological advancement, cultural integration, national unity and national development (Dienye and Morrison, 2012). According to Okoh in Morrison, Onyema, Igwe and Ogadi (2015), education is the process through which the ideals and worthwhile values of society are systematically passed on from one generation to another to ensure socio-cultural transformation and advancement of man and his environment. In the view of Hamilton (2013), education is any formal, informal, or non-formal system of activities people engaged in the society in order to prepare them with the appropriate skills, attitudes, knowledge, information and competences that will enable them participate and function effectively in socio-economic activities in the environment.

Moreso, Farell (2005), opine that girl- child education is the process of transforming the female-child with knowledge, skills, attitude, develop the power of self reliant and improve life chances. Women education is for making women becoming economically independent and self reliant (Agu, 2007). Women as mothers, are educators within their families, what they learn they pass on to their children and their future generations, Ainabor and Ovbiaele (2007).Therefore, education liberates the educated from the shackles of ignorance and that is why any nation that desires sustainable development invests in education, especially, that of girl child, Agbalajobi (2010).

Past researchers claim that there is a significant relationship between mother's educational level and the child (Afridi, 2010). Education of girl child has the potential of not only improving child health and intellect but also economic development. Girl child education means the process by which women acquire the knowledge, skills, norms and values that are necessary for their development and that of the society they belong. The benefits derived from education of girl child include the enhancement of the quality of living- food, housing, health, clothing, transport, communication, entertainment and gainful use of leisure. If the vast majority of our girl child are educated, their personal development can be enhanced remarkably. Children and husbands also stand to gain tremendously particularly in the hygiene and quality of food they cook for the families. Girl child are likely to have more confidence in themselves and their ability to contribute effectively to national development to eradicate poverty. If girl child is educated and empowered, they will be able to help in nation building and reconstruction and eradicate poverty.

Consequently, only a few women are holding powerful position in our country and in the world at large. For instance, during President Obasanjo's first term in office $(1999-2003)$, he appointed seven women as Ministers, while in the second term (2003 - 2007), he appointed more than seven women into his cabinet. He also appointed women as some of his advisers. The trend continuous to date. There is still room for improvement if more women are educated. Perhaps with more women holding the mantle in a male-dominated political arena, the sociopolitical state of affairs, the world over particularly Nigeria, will improve and poverty will be eradicated.

\section{CONCEPTUAL CLARIFICATION}

Education: Education is a term that has a wide range of connotations. It has been defined from the ancient time down to the present age; various concepts of education have been put forth by different scholars based on their philosophies of life, complex nature of human environment, different educational theories and practices as well as personality difference. Etymologically, education is coined out of two latin words: educere and educare which means to 'draw out' or 'lead out' and to 'nourish or bring up'. In drawing out or leading out, education helps to call out the innate tendencies, capabilities of a child for his benefit and the environment around him (Akinsayan, 2015).

The National Policy on Education (2004) Section $1(7)(d)$ state categorically that education is the process that helps to develop a total man, both physically, mentally, morally, politically, socially and environmentally in which they found himself. In Section 1(9) the policy states that; education shall be highly rated in the national development plans because education is the most important instrument of change, all fundamental change in the intellectual and social outlook of any society, has to be preceded by educational revolution. Therefore, FRN (2004) explained that education is an instrument par excellence for effecting sustainable development while Obot (2015) assert that education is a form of learning in which the knowledge, skills, attitude and habits of a group of people are transmitted from one generation to another through teaching, training or research autodidact or the guidance of an informal teacher. According to Akinsayan (2015), 
education is also considered as a social process which takes place in the society for the benefit of the society. Education is the transmission from one generation to another, the accumulated wisdom, knowledge, skills, values and attitudes of the society (Udoh, 2010). Education is viewed as having the capacity to perform corrective functions in the society. This is because, every wrong in the society is expected to be corrected by education. Education therefore aims at helping the individual develop a critical mind thus being able to attack any social problem intelligently. Programme called "Better Life Apprenticeship Trainings", a family support programme, etc came on board to reduce poverty to zero level but these programmes have not fully addressed the issue of poverty in the contemporary society. This paper advocates the need to emancipate, educate and empower the girl child to eradicate poverty in Nigeria.

Poverty: Poverty is an economic condition in which people do not have adequate level of health, housing, food and education, is viewed as being poor. According to United Nations (2008), poverty cannot be encapsulated in a particular human right, one single indicator cannot express poverty. Because poverty itself has stages, levels and degrees, that is why it differs from country to country and it is having an excessive nature of attributes.

Generally, it is the scenery of the position of poverty that results to hunger, lack of shelter and inability to secure basic health needs in family or society (Macionis, 2006). Reflecting on the complex nature of poverty, an array of terms in use, such as Income poverty, basic needs poverty, lack of sustainable livelihood, social exclusion, absolute and relative poverty, hopelessness and vulnerability. Nigerian position in poverty circle witness all of the attributes mentioned in various places, time and period. UNICEF (2000) has clarified that, poverty in some instance is narrowly confined to the using and interpretation of money based terms. This is by commonly defined deficient income to buy a minimum item of goods and services.

In conclusion, it is a recognized fact that education is a tool for economic, social and political development of a nation. it can be used in creating awareness for improving the standard of living of the people and for eradicating poverty in particular. Education, being a venture is expensive to manage. Even when governments invest in the sector by introducing free education as measure for reducing the cost, it is still difficult to manage. The cost of education includes tuition fees, cost on textbooks and other learning facilities. Though, some can afford to send their children to school, there is the probability of withdrawing them for lack of school fees. Poverty has denied many children access to education (Okemahinde, 2014). This increase the level of poverty as there is little or no job for such children.

Poverty has ripped the process of education apart and deprived people from getting proper access to education. Poverty has become the 'boss' with the help of corruption determining who should go to school and who should not. Poverty determines children's faith. Huge numbers of boys are dropping out of school, loaded with evil intention and sophisticated weapons declaring a war of robbery and rising cases of kidnappings while girls end up with early pregnancy, prostitution and other social vices being experienced across the nation and as such there is need for poverty to be effectively eradicated.

In the face of poverty, the girl child continues to be marginalized and discriminated with regard to obtaining quality education in Nigeria. The impact of poverty on education is of great significance and it is tormenting to see students struggling and battling the hardship to study without any support from the government. The Nigerian government has turned a deaf ear to the people's agony and blinded their eyes to the flood of poverty eroding our integrity and existence. Programs were launched by the governments which were supposed to alleviate poverty in the country but the effort was in vain due to selfinterest and corruption. The Nigeria government has failed and ignored the power of education on country development and providing an excellent human capital for the society.

Girl Child Education: Girl Child Education is the bedrock of women empowerment, be it formal or informal. Lere (2011) viewed education as the acquisition of knowledge, the aggregate of all the processes through which a person develops ability, skills, attitudes and other forms of behaviour with positive value in the society. It is a process through which a person acquires knowledge, skills, habits, and values that enable them to function effectively as a member of the society. Education helps one to maximize one's physical, mental and emotional capabilities which are useful to one and the society. In this sense, women education means the process by which women acquire the knowledge, skills, norms, and values that are necessary for their development 
and that of the society they belong. The benefits derived from education of womenfolk include the enhancement of the quality of living - food, housing, health, clothing, transport, communication, entertainment, and gainful use of leisure. Education aids in the fulfillment of women's obligation. Women are expected to take care of their husbands, children and in-laws. They are expected to use whatever knowledge and skills acquired to cook, clean and train their children. A girl child that is able to read about healthcare, body changes, modern household equipment, nutrition, etc will perform more effectively with her God given role in the home and society at large. An educated woman will be able to help her children with their academic work, e.g. assist them in their homework, and weak areas, attend Parents Teachers Association (P.T.A) meetings, etc. Girl child education goes a long way in reducing child abuse in the society Oluwole (2012). Women that are educated, take care of their children than those that are not. Education also modernizes the way of thinking, reaction to situations, dressing, etc of women.

According to the Federal Ministry of Agriculture and Rural Development, women account for $75 \%$ of the farming population in Nigeria, working as farm managers, and suppliers of labour (Sahel 2014) More than half of Nigerian population is women and two-third of agricultural work is done by them, about three-quarter of agricultural product in Nigeria is produced by their efforts (Adeyeye, 1987). Surprisingly, the women that participate most in agricultural production are the less educated. If the category of citizens are given basic education, it will no doubt ensure bumper agricultural production and poverty will be eradicated.

Women economic empowerment is low in Nigeria compared to their male counterparts. Many women still live on mental jobs (small scale business). Women, if educated, can embark on large scale business and also be of help to their husbands who are entrepreneurs and big time businessmen. They will be able to converse with such husbands intelligibly and even offer useful advice concerning their husbands' business partners, friends and other highly placed associates without the slightest feeling of inferiority. Educated and gainfully employed women can assist in financing the home and the education of their children and poverty will be eradicated.
The society could be improved through the development of the potentialities of the women folk, the 1978 General Conference of UNESCO agreed that increasing educational opportunities for the girl child boosts equity and fosters national development. The potential contribution of educated and trained women to the labour force and the importance of their education in the improvement of family welfare and planning are factors still underestimated in national development and therefore eradicate poverty.

It is pertinent to mention here that the higher the level of education, of a girl child, greater the likelihood that she will stay in the labour force. The participation of females with university degrees is more than double that of female who have only primary or secondary education. This creates an ever-increasing pool of experienced and skilled personnel among the female folk. Supervisory and managerial position can be filled by them and poverty will be eradicated out of Nigeria.

\section{THEORETICAL PERSPECTIVES}

Functional theorist like Auguste Comte (1789 1857), Emile Durkheim (1858 - 1917) and Spence 1820 - 1903 opined that the society can be likened to any living organism, with interrelated parts which functions have enormously for the survival of the society. Hence the need for the education of the girl child who will eventually be a future northern. Selective breeding is still in practice in some countries in Africa, where male children are sent to school female counterparts are left at home. This is detrimental to the development of the society.

On the other hand, the theory of monetary poverty was proposed by Laderchi, Saith, \& Stewart (2003). According to Laderchi et al., the monetary approach defines poverty in terms of how much a person's income (or consumption) falls short of minimum level of resources. The monetary approach to poverty measurement involves methodologies that emphasize monetary indicators and an objective derivation of the poverty line. The monetary approach is based on the assumption that a uniform monetary metric can be used to control for the heterogeneity of all the individuals and their situations. Pointed out that determining poverty based on a monetary metric entails the choice of an indicator, a unit of analysis, and a poverty line. A monetary indicator provides a common denominator of measurement for comparability Laderchi, et al., The dominant use of the monetary indicators to 
measure poverty is justified on the grounds that it can approximate aspects of poverty or well-being that are difficult to measure in the same unit. In addition, a monetary approach serves as a standard homogenous platform of poverty measurement that eases the tension between theoretical complexity and diversity of poverty definitions and measurements. The monetary approach emphasizes on the choice of income or expenditure indicator as a proxy for consumption as a proxy for permanent income. Laderchi et al., (2003) suggested a weakness of the monetary approach is its focus on the physical or moral character of the poor rather than the real causes of poverty. Traditionally, poverty is viewed as an individual problem, even though many of the causes of poverty can be traced to the household level. Laderchi et al., suggested that poverty analysis should consider the household as a unit of observation and the results of the analysis can be presented either at the household or individual level.

The choice of a poverty line is crucial to poverty measurement. A poverty line may be identified either with respect to a list of basic needs (absolute) or some characteristics of the distribution of the welfare indicators chosen (relative) (Ravallion, 1998). Ravallion's Food Energy Intake method underscores the level of income or expenditure at which food energy requirements are met. The lack of economic theory to determine minimal level of needs caused the estimation of the poverty line to be influenced by political debates and policy agenda. Therefore, the choice of poverty line has political be influence and lack of economic theory, the poverty line tends to be problematic and misleading (Laderchi et al., The theory is relevant because for any society to become modern, develop economically, socially and eradicate poverty, it must have an educated population with modern values, values for economic theory, standard and beliefs. This population must have good attitude towards work, quality life and the ability of controlling the environment. This theory is relevant in the sense that, the paper spearhead education as tools in ensuring eradication of extreme poverty through girl child education of a nation.

\section{CAUSES OF POVERTY IN NIGERIA}

Poverty is a situation where the victim is faced with economic, political and environmental problems. It has the potential of aggravating all forms of resentment which could, in some cases, become violent. It can be caused by unemployment, a situation in which persons, who are qualified for jobs and willing to work, cannot find jobs to do or suitable payment. This condition has prompted many youths to go into vices like robbery, child trafficking, kidnappings, militancy and prostitution, in attempts to eradicate poverty. Other causes includes:

High dependency on foreign goods can bring about poverty. This occurs when a nation depends solely on foreign goods instead of promoting the production of such goods at home. Such finished foreign goods are always expensive in terms of exchange rate.

Low level of investment is another cause of poverty. Investment in human capital, which is a process of developing human resources to acquire knowledge and skills, is still inadequate. This can be done through education and training of individuals in the society to improve their intellect and mental ability.

Low level of income is another cause of poverty. Most of the farmers practice subsistence agriculture. In this system, the costs of inputs are not commensurate with output. This creates a situation where the farmers can barely meet their basic needs for survival. Therefore, become prove to poverty.

Another cause of poverty is large population when compared with national income. The population is said to be more than the resources. This leads to low-income per capita resulting in poverty. This condition is caused when the wealth of the nation is concentrated in the hands of few individuals. Continuous economic slump and changes in labour often bring about poverty. In this situation, business drops and productive capacities decline. As it continues in this order, the situation of poverty is being aggravated.

\section{GIRL CHILD EDUCATION AND POVERTY ERADICATION IN NIGERIA}

Poverty is a ubiquitous phenomenon endemic in human society in general and Nigeria in particular. Therefore, it focuses on the achievement of the following:

i. Academic development

ii. Economic development

iii. Political development

iv. Moral development 
1. Girl Child Education and Academic Development

Educating the girl child will maximally weigh down the tempo of illiteracy in Nigeria, being one of the E-9 league of the countries by equipping and empowering children of the opportunity of acquiring the appropriate level of literacy, numeracy and manipulative skills for laying a solid foundation for life-long learning. This will turn Nigeria from poor to rich economy. Girls' education goes beyond getting girls into school. It is also about ensuring that girls learn and feel safe while in school have the opportunity to complete all levels of education acquiring the knowledge and skill to compete in the labour market, learn the socio-emotional and life skill necessary to navigate and adapt to a changing world, make decisions about their own lives, and contribute to their communities and the world.

\section{Girl Child Education and Economic Development}

In embracing the girl child education, all aspects of life be it academic or apprenticeship training, every beneficiary will be able to contribute her quota to the national economic development and stability. When job elasticity is created, then the unemployment syndrome will be stamped out of the nation. Education is one of the most important fundamental factor that affect economic development. None of the countries can achieve sustainable development by ignoring education. Education itself improves not just the productivity of workers or high-skilled ones, but also increases the productivity of farmers. So the greater the rate of schooling, the greater will be the investment on human capital in the society and the greater the increase in economic growth. Another important shift revolves around education, it has a permanent place in economists theory on human capital and modernization progress. So additional year of schooling will automatically raises the individual's earning power, wealth and life standards. Moreover, society's investment in human beings is a social investment as it is profitable. The fundamental contribution of education on economic growth is to increase the level of skills, talents, knowledge and experience of people to be more enable in the work force.
3. Girl Child Education and Political Development

There is a popular erroneous belief that politics is a dirty game, it has such in societies where education has not reformed the character of an individual. When every individual is accessible to education. People will be able to claim their rights of voting and being voted for in steering the destiny of the nation. The girl-child education as a major way of $s$ ensuring that women and girls are strategically positioned properly to contribute effectively and efficiently towards national development Okebukola (2014). Education is a vital tool to ensure the development of any country because it brings out and develops hidden potentials making the girl-child a useful contributor to her community and for the sustenance of national development by developing her attitude, skills and productivity level achieved through the teaching and learning process (Dauda, 2007).

\section{Girl Child Education and Moral Development}

Education without morals is like putting a gun powder near fire. In order to reduce immorality to the barest minimum. Considering the level of moral decadence among the youths of our time, girl child education will serve as putting a round peg in a round hole especially in entrenching an ethical reorientation of the entire citizenry, since all women are mothers.

\section{CONCLUSION}

Comparing the level of poverty in the country, there is no significant change. The problem of poverty is revolving round due to lack of proper and efficient education of the girl child that will enhance independent practices of selfemployment, by utilizing available natural resource for social security. Government and Non-Governmental Organizations (NGOs) have been devising different strategies to deal with the phenomenon but the monster is still everywhere. In Nigeria, successive administrators have adopted several strategies over the year to alleviate poverty but to no avail. It becomes obvious that there is still much work to be done to eradicate poverty in Nigeria. In order to achieve this, the girl child education should be totally embraced and the women folk should be empowered and also given the opportunity to develop their inherent human potential and equip them with relevant skills for self-reliance and selfemployment. 


\section{SUGGESTION}

To eradicate extreme poverty, the Nigerian government should rid their bodies of the virus of corruption and download the latest software of development and anti-poverty programmes to combat poverty by strengthening the capacity to provide quality education to all citizenry especially the girl child/women and the poor. This is by extending, visible education programme for all and should be relevant to state and community.

The Nigerian government should stop playing politics, but improve politics so as to provide access to education, by investing significant percentage of public budget in education. This will enhance educational efficiency by improving on skills, learning, entrepreneurship, and building of critical and objective reasoning in students to prevent passive attitude. Education should help to meet survival at any place regardless of the location and level of local development.

\section{REFERENCES}

Adeyeye, V. A., 1987. Women and development in Nigeria: An annotated bibliography and future research direction. A paper presented at the seminar on women's studies: The state of the art now in Nigeria. Institute of African Studies, University of Ibadan.

Afridi, F., 2010. Women's Empowerment and the Goal of Part between Sexes in Schooling in India, Population Studies, vol. 64 May 2010.

Agbalajobi, D.T., 2010. Women's Political Participation and Political Process in Nigeria; Prospect and Challenges. Journal of Political Science and International Relations. 4(2), 75-82

Agu, S., 2007 Gender Equality, Education and Women empowerment. The Nigeria Challenges. Multidisciplinary Journal of Research Development. 8(1), 66-72.

Ainabor, A. E and Ovbiagele, A. I., O., 2007. Implication of Women in Education for Poverty Alleviation in Nigeria. Journal of Academics. 1(1),13-20.
Akinsaya, P. O., 2015. Philosophy about education. Lagos: University of Lagos Press and Bookshop Ltd

Akubue, F. N. and Okolo, A. N., 2008. Sociology of education. Nsukka: Great AP Express Publishers Ltd.

Dauda, O.R., 2007. "Fmale Education in Nigeria's development strategies." Journal of Gender Studies. Vol. 14 (3).pp. 461-473.

Dienye V. U. and Morrison U. I., 2012. Integrating education religious, political and ethnic values for national interest: A Strategy for curbing violence in Nigeria. African Educational Journal 5 (2)7-13.

Esu, A. E. O., 2006. Education for humanistic value, in U. M. O. Irowi (Ed.), Education for value. Lagos: CIBN Press Ltd.

Fafunwa, A. B., 1971. History of Nigeria education. London: Group Ltd.

Falayajo, W. M. ,1997. Assessment of learning achievements. Lagos: F.G.N. UNICEF

Farrell, W., 2005. Why men earn more: the starting truth behind pay gap and what women can do about it. New York: AMACON. March, 2005.

Federal Republic of Nigeria, 2004. New national policy on education. Lagos: NERDC press

Hamilton, S. R., 2013. Redefining what education means to you. Available at: https://www.thespec.com/community.

Horton, P. B. and Hunt, C. L., 2006. Sociology, $\left(6^{\text {th }}\right.$ ed), New Delhi: Tata McGraw - Hill Publishing Company Ltd.

Laderchi, C., Saith, R. and Stewart, F., 2003. Does it matter that we do not agree on the definition of poverty: A comparison of four approaches. Oxford Development Studies, 31 (3), 233-274. 
Macionis, J. J., 2006. Sociology, $\left(10^{\text {th }}\right.$ ed), New Delhi: Dorling Kinder Sley (Indian) PVT Ltd.

Morrison, U. I., Onyema, P., Igwe O.I. and Ogadi C., 2015. Sociology of Education and Contemporary Issues in Nigeria: Cee Emmy lyke Ventures.

Okebukola, P.A.O., 2014. "Enhancing the Contribution of Sustainable Economic Development in Nigeria" Journal of Research in Education and Society Vol 5 (1) pp 224.

Okemakinde, T., 2014. Women Education: Implication for National Development in Nigeria European Journal of Globalization and Development Research 9(1), 553-564.
Oluwole A. O., 2012. Sexual abuse in Oyo and Osun state, publication of Daily Trust.

Ravallion, M., 1998. Poverty line in theory and practice. Washington D.C.: World Bank.

Sahel Capital Field Research, 2014.

Udoh, N. E., 2010. A sociology of education for Africa: A Comparative Study. Uyo: Saviour Publishers.

UNICEF, 2000. Poverty reduction begins with children. New York: Unicef. Retrieved August 12, 2009. From http://www.unicef.org/publication/index5616html.

United Nations, 2008. Millennium development goals report. New York: DESE 